\title{
Role of acupuncture in stress management
}

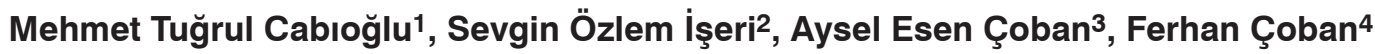

ABSTRACT: Stress factors impair physiological and psychological balance state of the individuals. This situation can cause various diseases. Today, diseases caused by stress are treated with methods like educational program for coping with stress, psychotherapy, drug therapy. Recently, acupuncture treatment is added to these methods. Acupuncture treatment effects to modulate various neurophysiologic mechanisms in during resistance period of stress. This mechanism provides support for the person's psychological state. Acupuncture treatment increases the secretion of hormones such as endomorphine, beta endorphine, enkephalin, serotonin and cortisol from central nervous system. Stress factors increase endomorphin, beta endorphin, enkephalin, serotonin and oxytocin levels in the central nervous system and plasma in the resistance period to stress. Acupuncture applications increase the synthesis and release of endomorphin, beta endorphin, enkephalin, serotonin and oxytocin from the central nervous system which strengthens the individual's resistance period to cope with stress. Therefore, method of acupuncture is also used in the treatment of diseases caused by stress.

KEY WORDS: stress, acupuncture, beta endorphin, enkephalin, serotonin, oxytocin

\section{INTRODUCTION}

Stress-related researches increased in recent years. Stress an inevitable part of modern life harms psychological and physiological health and relationships. Stress has been researched by many scientists from different scientific area such as biological sciences including physiology, biochemistry, neurophysiology and psychological sciences including psychoanalysis, developmental psychology and social sciences including the anthropology, sociology and history.

\section{What Is Stress?}

Hans Selye was an endocrinologist who spent much of his life studying the stress response. Selye pioneered the concept of biological stress as the interaction between a deforming force and the resistance to it. He noticed that both good news and bad news stimulated general response and he called negative stress distress and positive stress eustress. Selye saw stress as a nonspecific response of the body to any demand. This response affects the whole body or body systems in non-discriminatory manner (1). He developed
"The general adaptation syndrome (GAS)" model to describe the effect of chronic stressors on the body. GAS consists of three phases: the alarm reaction, the stage of resistance, and the state of exhaustion (2).

Canon also studied the physiology of stress and coined the term "Fight or flight" response that is commonly used to describe the way in which our body reacts to stress. The fight or flight response describes the way mammals respond to a threat. The first stage of the fight or flight response is activation of the sympathetic nervous system. This causes a system-wide response. The fight or flight response is designed for response to acute (or short-term) stressors, however many of the stressors that affect modern man may be chronic in nature (3).

\section{Stress Related Diseases and Management of Stress}

The aim of all the stress-related researches is to turn stress disturbed balance to a positive and motivational situation (4). Psychological symptoms of stress include anxiety, depression, in-
AFFILIATIONS

1Başkent University Medical Faculty, Physiology Department, Acupuncture Therapy Unit, Ankara, Turkey

2Hacettepe University Medical Faculty, Physiology Department, Ankara, Turkey

3Başkent University Faculty of Education, Psychological Counseling and Guidance Department, Ankara, Türkiye ${ }^{4}$ Başkent University Faculty of Health Sciences, Nursing and Health Care Department, Ankara, Turkey

\section{CORRESPONDENCE}

Sevgin Özlem İşeri

E-mail:

sevginiseri@gmail.com

Received:

24.01. 2012

Revision:

15.03.2012

Accepted:

16.03.2012 
somnia, impatience and intolerance while behavioral symptoms include pessimism, smoking and drug use $(5,6)$. It has been demonstrated that stress has a high cost to an individual's health and well-being and their productivity in the workplace (7). If symptoms of stress left untreated chronic diseases, such as coronary heart disease, hypertension, diabetes, ulcer and cancer may develope (8-10). The World Health Organisation estimates that stress-related disorders will become one of the second most common causes of disability by 2020 (11). A survey of general practitioners suggested that stress constitutes an "effectiveness gap" or an area of clinical practice in which available treatments are not fully effective (12).

Acupuncture, well established in China as part of the Traditional Chinese Medicine, is becoming more popular in western society each day (13). The reported symptoms of people who applied for the acupuncture treatment are often those related to stress (14). In 1976 a medical researcher discovered what he called the relaxation response which is the direct opposite of the fight or flight response (15). Both the fight or flight response and the relaxation response are mediated by the autonomic nervous system which is composed of the sympathetic nervous system and the parasympathetic nervous system. These branches of the nervous system are like the yin and the yang of the body. Yin and yang are the two forces in Chinese medicine working together and in balance. In the body, this duality is expressed in the qi (yang) and the blood (yin) as two separate circulation systems. The concept of qi is analogous to the pneuma of Stoic and Greek medicine (16). Qi and pneuma are untranslatable but could be called life-breath, subtle influence or ethereal - a rarefied form of energy. While the blood is pumped by the heart and circulates through the arteries, veins and capillaries, the qi is generated by the lungs and flows through invisible tracts called meridian in the body (17). An appropriate balance between the two systems is essential for the good health and functioning.

Many different ways help individuals to cope with stress which include psychological counseling, guidance services, educational programs, psychotherapeutic approaches, drug therapy, herbal treatments and additionally acupuncture treatment are effectively used for stress reduction.

\section{Adaptive Reaction to Stress, Systemic Defense of The Body}

a. General Adaptation Syndrome (GAS)

b. Local Adaptation Syndrome (LAS):

GAS is elicited only by stressors that directly or indirectly affect the whole body. On the other hand, a Local Adaptation Syndrome (LAS) is the response to nonspecific demands upon only one part of the body. Following physically or chemically traumatized region of skin or connective tissue, LAS will be inflammation, necrosis or cell degeneration with regeneration. However, an intense LAS (e.g. in a limited muscle group, sense organ or brain region) may reach such areas as to affect the whole body and produce GAS through its secondary systemic stressor effects (2).

A. Alarm Phase: This is the immediate response to a challenge or threat. Mobilization of the autonomic nervous system triggers the stress response ("fight or flight" response). The various body systems involved coordinate the readiness for action,

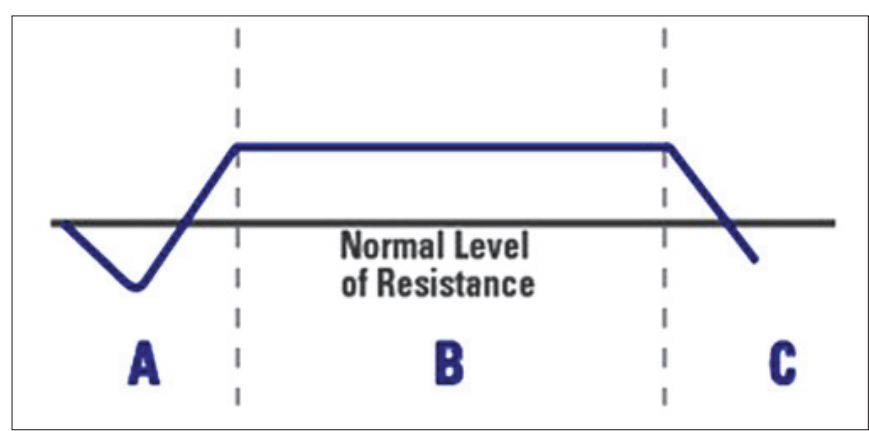

FIGURE 1. The three phases of the general adaptation syndrome (GAS).2 A Alarm Phase, B: Resistance or adaptation phase C: Exhaustion phase

influencing mood (limbic system), the regulation of the cardiovascular system, breathing, muscle tension, and fine motor activities.

B. Resistance or Adaptation Phase: The alarm reaction cannot be maintained indefinitely, and longer exposure to stressors causes people to reach the resistance stage. In this phase people develop a "survival" strategy and a way of fighting against the stressor is initiated.

Coping mechanisms may be adequate or inadequate. People tend to prefer short term relief to long term solutions and try to escape uncomfortable situations with a quick remedy. Unfortunately, most easy, short term measures are inadequate because they usually lead to secondary problems such as long term reduction in performance. People need help to identify measures that can lead to long term benefit. Acupuncture treatment modulates various neurophysiologic mechanisms during resistance period to stress.

C. Exhaustion Phase: The stress response is healthy in origin and is necessary to keep a person motivated and adaptable. Prolonged stress can lead to chronic problems, ultimately an exhaustion of all reserves and energies and even depression. If adaptation is not successful, sustained stress can damage the compensatory mechanisms (18) (Figure 1).

IV. Neuroendocrine response of the body to stress factors When a threat to homeostasis is perceived, hypothalamus-pituitary-adrenal (HPA) axis is activated as an important regulatory mechanism of the stress response. Exposure to different types of stressors causes, neuroendocrine and behavioral responses that include the activation of the hypothalamus-pituitary-adrenal (HPA) axis which are mostly designed to re-establish homeostasis and allow the individual to cope with stress conditions. It was proven that oxytocin, a nonapeptide released from the posterior pituitary, has behavioral and stress-attenuating effects by dampening HPA activity (19). HPA axis activity is governed by the secretion of corticotrophin-releasing hormone $(\mathrm{CRH})$ from the hypothalamus, which activates the secretion of adrenocorticotropic hormone (ACTH) from the pituitary. ACTH, in turn, stimulates the secretion of glucocorticoids from the adrenal glands. Exposure to a variety of stimuli triggers the hypothalamic paraventricular nucleus to release OT into OT receptor rich cortical, limbic, and brainstem regions associated with emotion and heterarchical control of neuroendocrine functioning (20). OT consid- 
ered to be one of the major regulator of the neuroendocrine and behavioral stress management. OT dampens HPA axis reactivity to social stress in humans and rodents $(21,22)$.

\section{IV.a. The role of cortisol, epinephrine and norepinephrine in stress response}

Glucocorticoids interact with the corticosteroid receptors, which are present in almost every tissue in the body. Cortisol affects a multitude of systems in the body, including the HPA axis itself, the cardiovascular system, the immune system, metabolism, and cell growth, and it also has an impact on behavior.

Stress factors, through the sympathetic nervous system, affect cerebral cortex, limbic system and the HPA axis and as a result stimulate adrenal medulla to secrete epinephrine, norepinephrine, beta-endorphin (BE), enkephaline and dopamine.

Cortisol, released as a response to stress factors, increases glycogenolysis, glyconeogenesis, protein synthesis by facilitating the entry of amino acids in to hepatocytes and mobilizes fatty acids from the adipose tissue, inhibits inflammation via reducing diapedesis of the leukocytes, decreases the immunoglobulin count by lymphoid tissue atrophy, decreases eosinophil and white blood cell counts while increases red blood cells, reduces the amount of histamine so inhibits allergic reactions. In addition, cortisol increases the blood pressure via increasing the sensitivity of blood vessels to epinephrine and increasing the production of angiotensin in the liver. Cortisol causes the hypersecretion and hyperacidity of the gastrointestinal system, and also increases mental activities as a result of the central nervous system activation.

Stress factors, via the sympathetic component of the autonomic nervous system cause the release of the epinephrine and norepinephrine from adrenal medulla to the plasma. Norepinephrine effects peripheral circulation via alpha-receptors, while epinephrine stimulates heart and lipolysis via beta-1 receptors and causes bronchodilatation via beta- 2 receptors.

Epinephrine increases cardiac muscle contractility and heart rate, increases respiratory rate, bronchodilatation, reduces glomerular filtration, activates renin-angiotensin aldosterone system and depend on the increase in aldosterone, accelerates the retention of salt and water in the body, increases glycogenolysis, mobilizes fatty acids from the adipose tissue, increases respiratory depth and rate, causes pupillar dilatation, increases mental activity, causes vasoconstriction of the superficial veins of the skin.

\section{IV.b. Neuroendocrine system and stress management}

Rise of the plasma cortisol and epinephrine level play a role to overcome the stress factors during the body's resistance period. If the stress factors are too strong or sustained for a very long period of time, body can not cope with stress factors during the resistance period. Therefore, the period of exhaustion starts which cause many psychosomatic illnesses, or cause the exhaustion of the organism completely.

Serotonergic nervous system also plays a role in the adaptation to stress factors. Postsynaptic 5-hydroxytryptamine level is increased during adaptation to repeated shortor long-term stresses (23). Sympathetic nervous system stimulation during stress cause epinephrine, norepine- phrine and dopamine release from adrenal medulla into the bloodstream (20). Pathological effects of stress are suppressed by endogenous opioids released into bloodstream during stress (24). Intracerebroventricular and intraperitoneal (ip) injections of the opioid peptides reduced the gastric acid secretion, ip injections at the same time increased the production of prostaglandin in the gastric mucosa (25). Studies have shown that suckling during the post-partum period is associated with decreased HPA axis activity (26) and that lactating rats demonstrate blunted adrenocorticotropic hormone (ACTH) and cortisol secretion to various forms of stressors (27). Oxytocin (OT) displays a role in a variety of social behaviors, including maternal care and aggression, pair-bonding, sexual behavior, social memory and support, it is an important regulator of the stress response via its inhibitory effects on HPA responses in the regulation of stress response (28). Chronic treatment of female rats with oxytocin results in a transient increase in corticosterone, followed by sustained suppression of the HPA axis (29). Moreover, OT injections have been associated with decreased cortisol levels in female rats (30), anxiolytic-like effects and sedation in male rats (31).

Central OT has been shown to attenuate hormonal stress responsiveness of the HPA axis and to decrease anxiety by decreasing the sympatho-adrenal and HPA tonus, and increasing the vagal nerve tonus (32).

Stress can trigger inflammatory responses in different organs and sustained stress can trigger or exacerbate chronic inflammatory diseases. Plasma ACTH and cortisol levels increase with exposure to stress and the same stress response also occurs with the experimental burn injury. According to research results of Işeri et al. OT with the stress-reducing effect found effective for the treatment of burn-induced wounds and prevention of the following remote organ injury. Social environment increase the level of the OT and mimic the effect of OT therapy. Due to the significant influence of OT, social isolated individuals have found more susceptible to delayed wound healing and burn-induced intestinal damage and further complications (33).

\section{The role of acupuncture on stress reduction}

Acupuncture is a therapy of inserting, manipulating and retaining very fine needles in specific "acupoints". Over the years several studies have investigated the effect of acupuncture on 'psychological stress' and anxiety using different acupuncture points, and most described positive results.

Acupuncture therapy controls stress via increasing the levels of enkephaline in the CNS and plasma (34). Enkephalins are endogenous opioid peptides regulate mood and psychological state. Enkephalins have antidepressant, anticonvulsant and anxiety-relieving effects (35). Acupuncture application increases the plasma levels of $\mathrm{BE}$ and $\mathrm{ACTH}(36,37)$ via increasing the release of $\mathrm{BE}$ and $\mathrm{ACTH}$ from the anterior lobe of the pituitary gland (38). In addition to elevated endogenous opioids, serotonin levels in the CNS are also increased with acupuncture treatment (39). Serotonin regulates the mood, prevents depression, makes people feel good and happy, modulates appetite and sexual behavior and psychomotor balance (40). Increased serotonin level in the CNS and plasma as a result of acupuncture treatment, modulate mood and psycho- 


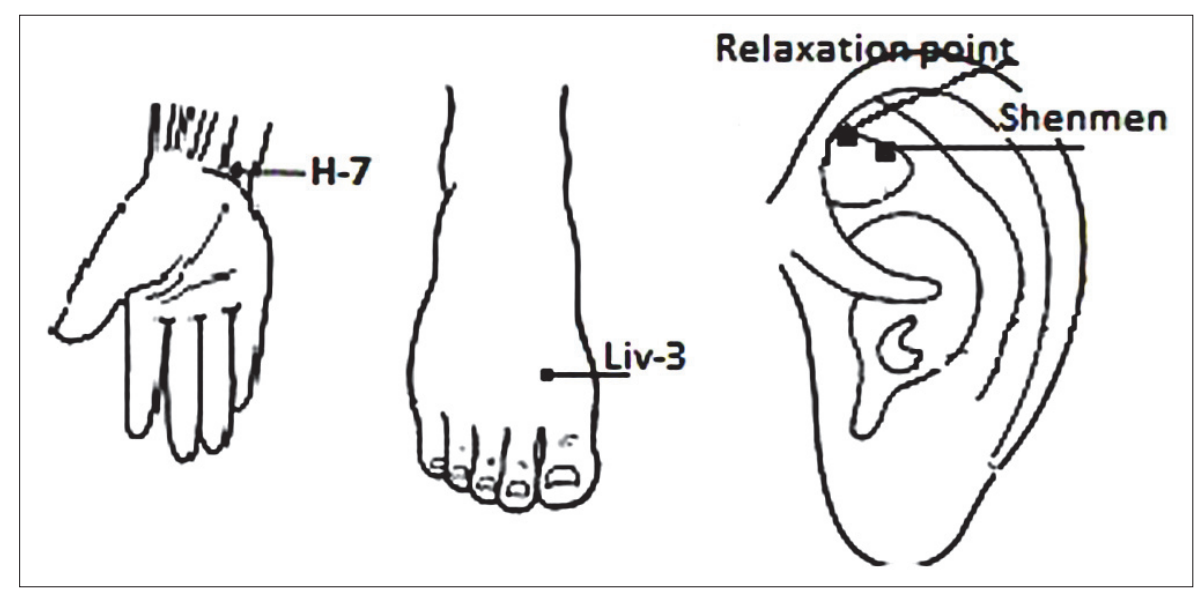

FIGURE 2. Acupuncture points with anxiolytic effect.

logical state and that result partly explains why acupuncture is used to successfully treat anxiety and depression (41).

Research results suggest that acupuncture treatment effects the concentration of OT at the spinal cord and the brain nuclei. Additionally, OT levels at the CNS has been shown to have an important role in acupuncture analgesia (42). Another study investigated the anxiolytic and antioxidant effect of OT in rats with stress-induced colitis and results showed that the effects of OT occur through OT receptors (43). Anxiolytic effect of acupuncture treatment, may be due to an increase in the central nervous system OT level following the acupuncture treatment.

Cabığlu et al. treated group of obese patients with acupuncture plus diet or diet only and measured weight loss, plasma ACTH, BE and cortisol levels of all patients. Results of this study showed that patients, treated with acupuncture and diet together, had higher plasma ACTH, BE and cortisol levels and had higher weight loss comparing to patients treated with diet alone. Acupuncture points were selected according to the literature. Hungry, Shenmen and Stomach point for ear acupuncture, LI4, LI11, St25, St36, St44, Liv3, and Sp3 for body acupuncture points were selected for the treatment of obesity (44). Shenmen (45) and Liv3 (46) acupuncture points were recorded to have significant effect in reducing anxiety scores (Figure 2).

In another study, Cabığlu et al. treated 165 volunteer obese women with acupuncture, sham Acupuncture or diet. The group of women treated with acupuncture lost more weight compared to the other two groups, in addition to that a reduction in the psychological symptoms such as phobias, anger, anxiety, obsession, paranoid symptoms were also observed in the acupuncture treated group (47). The results showed that acupuncture application is effective in weight loss and the treatment of psychological symptoms of obesity as well. Chang and colleagues showed that the stimulation the Jen-Chung acupuncture point activated the brain noradrenergic system (48). Chang et al. in their study applied acupuncture to ST-36 acupuncture point to create the central serotoninergic system activation and detected analgesic effect via 5-HT (1A) and 5-HT (3) receptors (49). Guo et al. in their study with cats, applied acupuncture to the P5-P6 acupuncture points and successfully activated the opioid system at the arcuate nucleus of the hypothalamus (50). Kishioka et al. showed that the Hoku acupuncture point stimulation increased met-enkephalin, BE and dynophin levels which caused pain-reducing effect (51). Zhou et al. detected increased leu-enkephaline and BE levels at nucleus reticularis paragigantocellularis after acupuncture stimulation of rats and found that increased level of endogenous opioids correlated with the elevation of pain threshold. Their result also revealed that increased pain threshold with acupuncture treatment decreased when nucleus reticularis paragigantocellularis were injured (52).

Acupuncture needle stimulation (Electroacupuncture) are often used for mental problems such as depression (30), anxiety (41), insomnia $(53,54)$, obsession (47) and panic attack (47). Different frequencies of electroacupuncture application cause the release of different neurotransmitters from the central nervous system such as endomorphin, enkephalin and BE released at low frequency electroacupuncture $(2 \mathrm{~Hz})$ while dinorphin released at high frequency electroacupuncture $(100 \mathrm{~Hz})(55)$.

One commonly reported action of acupuncture is the stress reduction. The acupuncture treatment was associated with less stress both before and after embryo transfer, and it improved pregnancy rates (56). A stress response causes vasoconstriction, which could acutely decrease uterine perfusion, it seems plausible that excessive stress on the day of embryo transfer (ET) could lower pregnancy rates. It also seems that techniques that elicit the relaxation response, leading to vasodilation, at the time of ET could improve pregnancy rates (57).

Traditionally HT7 acupuncture point can be used to calm spirit and to pacify the Heart. Translating into western terms, to settle palpitations, helps with insomnia and stress and can be helpful in angina pectoris (58). It has always been known to be one of the major sedating points. In a series of 800 cases, whilst using the auricular points Shenmen and Stomach in an attempt to treat obesity, Apostolopoulos noted a reduction in anxiety in $46.7 \%$ of 697 patients (59). In a cohort study $(n=68)$, Dong used the Hospital Anxiety and Depression Scale (HAD), and demonstrated 42 out of 60 anxiety scores had returned to normal after one month of treatment (60). In a controlled trial of the treatment of anxiety $(n=240)$, Guizhen et al compared acupuncture 


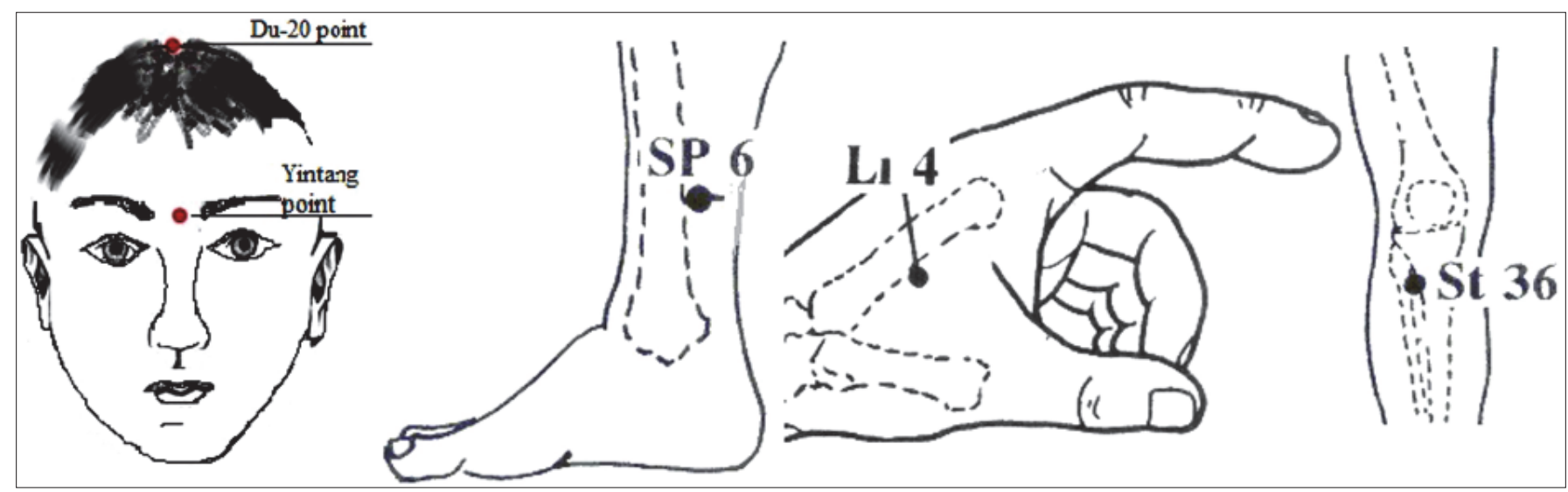

FIGURE 3. Acupuncture points used for the stress treatment by researchers.

TABLE 1. Findings of studies on stress reduction with acupuncture treatment.

\begin{tabular}{|c|c|c|c|c|c|c|}
\hline & $\begin{array}{l}\text { Electroacupuncture for } \\
\text { Primary Insomnia: } \\
\text { A Randomized Controlled } \\
\text { Trial (54). }\end{array}$ & $\begin{array}{l}\text { Acupuncture Increases } \\
\text { Nocturnal Melatonin } \\
\text { Secretion and Reduces } \\
\text { Insomnia and Anxiety. } \\
\text { A Preliminary Report (53) }\end{array}$ & $\begin{array}{l}\text { Auricular acupuncture: } \\
\text { A potential treatment for } \\
\text { anxiety (45) }\end{array}$ & $\begin{array}{l}\text { An uncontrolled pilot } \\
\text { study of HT7 for } \\
\text { "stress". (58) }\end{array}$ & $\begin{array}{l}\text { The relationship between } \\
\text { perceived stress, } \\
\text { acupuncture, and pregnancy } \\
\text { rates among IVF patients: } \\
\text { A pilot study. (56) }\end{array}$ & $\begin{array}{l}\text { Acupuncture is effective } \\
\text { to attenuate stress and } \\
\text { stimulate lymphocyte } \\
\text { proliferation in the elderly. } \\
\text { (62) }\end{array}$ \\
\hline $\begin{array}{l}\text { Study } \\
\text { population }\end{array}$ & $\begin{array}{c}\text { Chinese volunteers } \\
\text { who have an insomnia } \\
(n: 60)\end{array}$ & $\begin{array}{c}\text { Anxious adults } \\
\text { who complained of insomnia } \\
\text { (age: } 25-55 \text { years; } 11 \mathrm{~F}, 7 \mathrm{M} \text { ) } \\
\text { (n:18) }\end{array}$ & Adult volunteers (n: 55), & $\begin{array}{l}\text { Healthy volunteers } \\
\text { (n:17) }\end{array}$ & $\begin{array}{l}\text { Infertile patients undergoing } \\
\text { IVF or IVF/ICSI (n: } 57)\end{array}$ & $\begin{array}{c}\text { (age: 23-38 years; } 6 \text { F, } 6 \mathrm{M}) \\
\text { and (age: 60-81 years; } \\
6 \text { F, } 6 \mathrm{M})(\mathrm{n}: 24)\end{array}$ \\
\hline $\begin{array}{l}\text { Acupuncture } \\
\text { points }\end{array}$ & $\begin{array}{l}\text { Yintang (EX-HN3), } \\
\text { Baihui (GV20),bilateral ear } \\
\text { Shenmen, Sishencong } \\
\text { (EX-HN1), and Anmian (EX) }\end{array}$ & $\begin{array}{l}\text { Symptomatic } \\
\text { acupuncture points }\end{array}$ & $\begin{array}{l}\text { Bilateral ear acupuncture points: } \\
\text { "shenmen" point or } \\
\text { "relaxation" point }\end{array}$ & Bilateral HT7 & $\begin{array}{l}25 \text { min. before ET: Cx6 } \\
\text { (Neiguan), Sp8, Liv3, } \\
\text { Gv20, and ST29. } \\
\text { After ET: ST36, Sp6, } \\
\text { Sp10, and Li4 }\end{array}$ & $\begin{array}{l}\text { Bilateral acupoints LI4, } \\
\text { SP6 and ST36. }\end{array}$ \\
\hline $\begin{array}{l}\text { Study } \\
\text { Objectives }\end{array}$ & $\begin{array}{l}\text { To evaluate the short-term } \\
\text { efficacy and safety of } \\
\text { electroacupuncture for the } \\
\text { treatment of primary insomnia }\end{array}$ & $\begin{array}{l}\text { The response to } \\
\text { acupuncture of } \\
18 \text { anxious adult }\end{array}$ & $\begin{array}{l}\text { the effectiveness of } \\
\text { acupuncture in } \\
\text { reducing anxiety }\end{array}$ & $\begin{array}{l}\text { Effect of needling } \\
\text { at HT7 }\end{array}$ & $\begin{array}{l}\text { Determine the effect of } \\
\text { acupuncture on perceived } \\
\text { stress levels in women on } \\
\text { the day of } E T \text {, and } \\
\text { to determine the correlation } \\
\text { with pregnancy rates. }\end{array}$ & $\begin{array}{l}\text { Effects of acupuncture on } \\
\text { stress-related psychological } \\
\text { symptoms and cellular } \\
\text { immunity in young adults and } \\
\text { elderly subjects. }\end{array}$ \\
\hline Study design & $\begin{array}{l}\text { Randomized, single-blind, } \\
\text { placebo-controlled, } \\
\text { parallel-group }\end{array}$ & $\begin{array}{l}\text { open prepost clinical } \\
\text { trial study }\end{array}$ & $\begin{array}{l}\text { using repeated-measures } \\
\text { analysis of variance, } \\
\text { Post hoc analysis }\end{array}$ & $\begin{array}{l}\text { uncontrolled } \\
\text { pilot study }\end{array}$ & $\begin{array}{l}\text { observational, prospective, } \\
\text { cohort study based at the } \\
\text { University IVF center. }\end{array}$ & $\begin{array}{l}\text { Clinical study using analysis of } \\
\text { variance }\end{array}$ \\
\hline Measurements & $\begin{array}{l}\text { Self-reported questionnaires, } \\
\text { 1-week sleep diaries, } \\
\text { 3-day actigraphy at baseline } \\
\text { and } 1 \text { week after treatment. }\end{array}$ & $\begin{array}{c}\text { melatonin secretion } \\
\text { (as measured in urine), } \\
\text { polysomnographic measures } \\
\text { of sleep, Zung anxiety self } \\
\text { rating scale }\end{array}$ & $\begin{array}{c}\text { State anxiety, blood pressure, } \\
\text { heart rate, and } \\
\text { electrodermal activity were } \\
\text { assessed at } 30 \text { min, } \\
24 \mathrm{~h} \text {, and } 48 \mathrm{~h} \text { after insertion }\end{array}$ & $\begin{array}{l}\text { Edinburgh Postnatal } \\
\text { Depression Scale } \\
\text { (EPDS) before each } \\
\text { treatment and } \\
1 \text { week following } \\
\text { last treatment }\end{array}$ & $\begin{array}{c}\text { Perceive Stress Scale scores, } \\
\text { pregnancy rates }\end{array}$ & $\begin{array}{l}\text { Psychological variables } \\
\text { were investigated by self- } \\
\text { assessment inventories. } \\
\text { PBMC isolated-cultured } \\
\text { in vitro to measure T-cell } \\
\text { proliferation }\end{array}$ \\
\hline Duration & 3 times per week for 3 weeks & $\begin{array}{l}5 \text { weeks (two sessions per } \\
\text { week, } 10 \text { sessions in total) } \\
\text { (each session lasts for } 1 \text { hour) }\end{array}$ & $\begin{array}{l}\text { Press-acupuncture needles } \\
\text { were inserted at the respective } \\
\text { auricular areas for } 48 \mathrm{~h} \text {. }\end{array}$ & $\begin{array}{l}\text { weekly intervals } \\
\text { for } 4 \text { weeks }\end{array}$ & $\begin{array}{l}25 \text { min. Before and } \\
\text { after ET.(each session lasts } \\
\text { for } 25 \text { min.) Control group } \\
\text { remained only lying still. }\end{array}$ & $\begin{array}{c}6 \text { sessions, } \\
2 \text { times a week }\end{array}$ \\
\hline $\begin{array}{l}\text { Clinical } \\
\text { significance }\end{array}$ & $\begin{array}{l}\text { Significant improvements } \\
\text { in sleep efficiency by sleep } \\
\text { diary and actigraphy in the } \\
\text { electroacupuncture group. }\end{array}$ & $\begin{array}{l}\text { Significant increase in nocturnal } \\
\text { melatonin secretion ( } \mathrm{p} \text { : } 0.002) \\
\text { and improvements of sleep } \\
\text { onset latency ( } \mathrm{p}: 0.003) \text {, arousal } \\
\text { index ( } \mathrm{p}: 0.001) \text {, total sleep } \\
\text { time (p:0,001), sleep efficiency } \\
\text { (p:0.002) and reduction in } \\
\text { anxiety scores ( } \mathrm{p}: 0.004) \text { with } \\
\text { acupuncture treatment. }\end{array}$ & $\begin{array}{l}\text { A significant difference in } \\
\text { anxiety levels (P:0.001) between } \\
\text { the three groups. Patients } \\
\text { treated with Relaxation point } \\
\text { were significantly less anxious } \\
\text { at } 30 \text { min ( } \mathrm{P}: 0.007) \text { and } 24 \mathrm{~h} \\
\text { (P:0.035) compared to patients } \\
\text { in both the Shenmen treated } \\
\text { group and the Sham group, and } \\
\text { less anxious at } 48 \mathrm{~h}(\mathrm{P}: 0.042) \\
\text { compared to Shenmen group. }\end{array}$ & $\begin{array}{l}\text { The greatest fall in } \\
\text { the EPDS scores was } \\
\text { observed within } \\
\text { the first two treatments. } \\
\text { At the end of the study, } \\
\text { there was an average } \\
\text { reduction of } 44 \% \\
\text { in the EPDS scores. }\end{array}$ & $\begin{array}{c}\text { With AT, achieved } \\
\text { pregnancy were } 64.7 \% \text {, } \\
\text { without AT achieved } \\
\text { pregnancy were } 42.5 \% \text {. } \\
\text { Non-donor recipients potentially } \\
\text { had an improvement with AT } \\
\text { (35.5\% without AT vs. } \\
55.6 \% \text { with AT). } \\
\text { Women with AT had lower } \\
\text { stress scores both } \\
\text { pre-ET and post-ET } \\
\text { compared to those who did not. }\end{array}$ & $\begin{array}{l}\text { Acupuncture was able to } \\
\text { significantly } \\
\text { reduce depression } \\
(p<0.001) \\
\text { anxiety }(p<0.001) \text { and } \\
\text { stress }(p<0.001) \text { scores. }\end{array}$ \\
\hline $\begin{array}{l}\text { Author } \\
\text { Conclusion }\end{array}$ & $\begin{array}{l}\text { AT have an effect on sleep } \\
\text { efficiency. }\end{array}$ & $\begin{array}{l}\text { Acupuncture Reduces } \\
\text { Insomnia and Anxiety. }\end{array}$ & $\begin{array}{l}\text { Auricular acupuncture } \\
\text { at the "relaxation" } \\
\text { point can decrease the anxiety } \\
\text { level in a population } \\
\text { of healthy volunteers. }\end{array}$ & $\begin{array}{l}\text { Bilateral AT at HT7 was } \\
\text { an effective method for } \\
\text { reducing the rating of } \\
\text { 'psychological stress' }\end{array}$ & $\begin{array}{l}\text { AT was associated with less } \\
\text { stress both before and after } \\
\text { embryo transfer, and it possibly } \\
\text { improved pregnancy rates. }\end{array}$ & $\begin{array}{c}\text { Acupuncture was efficient to } \\
\text { attenuate the psychological } \\
\text { distress as well as to increase } \\
\text { an important feature of cellular } \\
\text { immunosenescence. }\end{array}$ \\
\hline
\end{tabular}

alone (AO), behavioral desensitisation alone (DO) and combined acupuncture with behavioural desensitisation (CAD). The cure rates after a course of therapy were reported as $20 \%$ (AO), 26.3\% (DO) and 52.5\% (CAD) (61). Pavao et al. demonstrated that repeated applied acupuncture was effective to at- tenuate stress and stimulate lymphocyte proliferation in both young and elderly populations (62) (Table 1) (Figure 3).

As a result, various theories and methods used are emphasized in the literature to cope with or to adapt to stress which has negative effects on human. According to Sahin's research to 
cope with stress is to learn to handle stress always at the positive level (63). Researchers like Fields and Prinz (64), and Lazarus and Folkman (4) described coping with stress as the organisms ever-changing cognitive and behavioral efforts to adapt to the depletion of own physio-psychological resources. The individual is trying many ways to pass a state of balance again as a result of stress-induced degradation of psychological balance. Unhealthy ways also tried to prevent to cope with stress. In this context, a variety of services are offered to help for a healthy and effective way to cope with stress.
Acupuncture treatment increases the endomorphin, epinephrine, norepinephrine, BE, and enkephalin levels of CNS and plasma. The increase of these neurotransmitters in the CNS and plasma strengthens body resistance against stress. According to all results of the studies up to date we conclude that acupuncture treatment is one of the cost effective treatment to prevent and reduce stress and prevent stress-induced illnesses. This should be considered when choosing a stress-reduction strategy.

\section{Stresle başetmede akupunktur tedavisinin rolü}

ÖZET: Stres faktörleri kişinin fizyolojik ve psikolojik denge durumunu bozmaktadır. Bu durum çeşitli rahatsızlıklara neden olmaktadır. Günümüzde, stresin neden olduğu hastalıkların tedavisinde stresle baş etme eğitim programı, psikoterapi, ilaç tedavisi gibi yöntemler kullanılmaktadır. Son zamanlarda, bu yöntemlere akupunktur tedavi yöntemi de ilave edilmiştir. Akupunktur tedavi yöntemi kişinin stresle baş etme sürecinde çeşitli nörofizyolojik mekanizmaları harekete geçirmektedir. Bu mekanizmalar kişinin psikolojik durumuna destek sağlamaktadır. Akupunktur tedavisi, merkezi sinir sisteminden endomorfin, beta endorfin, enkefalin, serotonin ve kortizol gibi hormonların salgılanmasını düzenlemektedir. Stres faktörlerine maruz kalma, MSS'de ve plazmada endomorfin, beta endorfin, enkefalin, serotonin, oksitosin düzeyinin yükselmesine neden olarak strese karşı direnç dönemine neden olur. Akupunktur uygulamaları, endomorfin, beta endorfin, enkefalin, serotonin, oksitosin'in MSS'de sentez ve salınımını arttırarak, kişinin stresle baş etmedeki direnç dönemini güçlendirmektedir. Bundan dolayı, akupunktur yöntemi stresin neden olduğu hastalıkların tedavisinde de kullanılmaktadır.

ANAHTAR KELIMELER: stres, akupunktur, beta endorfin, enkefalin, serotonin, oksitosin.

\section{REFERENCES}

1. Selye H. Stress without distress. J. B. Lippincott Co, Philadelphia. 1974.

2. Selye H. Forty years of stress research: principal remaining problems and misconceptions. Can Med Assoc J 1976; 115: 53-6.

3. Cannon WB. Stresses and strains of homeostasis. Am J Med Sci 1935; 189: 1-4.

4. Lazarus RS, Folkman S. Stress, appraisal, and coping. Springer Publishing Company, New York. 1984.

5. Avison WR, Gottlieb IH. Stress and mental health: Contemporary issues and prospects for the future. Plenum Press, New York. 1994.

6. Jordan I, Spangenberg JJ, Watson MB, Fouche P. Emotional stress and coping strategies in South African clinical and counselling psychologist. South Afr J Psychol 2007; 37: 835-55.

7. Cooper CL, Dewe PJ, O'Driscoll MP. Organizational stress: a review and critique of theory, research, and applications. SAGE, London. 2001.

8. Jonathon DG. Health consequences of stress. J Orga Behav Manage 1986; 8: 19-36.

9. Chandola T, Britton A, Brunner E, Hemingway H, Malik M, Kumari M, et al. Work stress and coronary heart disease: what are the mechanisms? Eur Heart J 2008; 29: 640-8.
10. Rosmond R, Bjorntrop P. The hypothalamicepituitaryeadrenal axis activity as a predictor of cardiovascular diseases, Type 2 diabetes and stroke. J Intern Med 2000; 247: 188-97.

11. Greener M. Guide to managing stress. The Penguin Group, London. 2002.

12. Fisher $P$, van Haselen $R$, Hardy $K$, Berkovitz $S$, McCarney R. Effectiveness gaps: a new concept for evaluating health service and research needs applied to complementary and alternative medicine. J Altern Complem Med 2004; 10: 627-32.

13. Baldry P. The integration of acupuncture within medicine in the UK. Acupunct Med 2005; 23: 2-12.

14. Alltree $J$. Physiotherapy and acupuncture: practice in the UK. Complement Ther Med 1993; 1: 34-41.

15. Payne R. Relaxation Techniques - A Practical Handbook for the Health Care Professional 3rd ed. Churchill Livingstone, New York. 2005.

16. Needham JL. Science and civilization in China. VI. Cambridge Univ. Press, Cambridge. 1954-2000.

17. Temple R. The genius of China: 3,000 years of science, discovery and invention. Simon and Schuster, New York. 1986.

18. McEwen BS. Protective and damaging effects of stress mediators. New England J Med 1998; 338: 171-9.

19. Yeğen $B C ̧$. Oxytocin and hypothalamo-pituitaryadrenal axis. Marmara Pharm J 2010; 14: 61-6. 
20. Gimpl G, Fahrenholz F. The oxytocin receptor system: structure, function, and regulation. Physiol Rev 2001; 81: 629-83.

21. Heinrichs M, Baumgartner $T$, Kirschbaum C, Ehlert U. Social support and oxytocin interact to suppress cortisol and subjective responses to psychosocial stress. Biol Psychiatry 2003; 54: 1389-98.

22. Windle RJ, Shanks $N$, Lightman $S L$, Ingram $C D$. Central oxytocin administration reduces stress-induced corticosterone release and anxiety behavior in rats. Endocrinology 1997; 138: 2829-34.

23. Hayashi $M$, Takeda $H$, Takada $K$, Inazu $M$, Tsuji $M$, Matsumiya T. Age-related decline in emotional adaptability to short-term stressful situation: The participation of the monoaminergic nervous systems in the cerebral limbic system. Pathophysiology 1998; 5: 125-30.

24. Glavin GB. Effects of morphine and naloxone on restraintstress ulcers in rats. Pharmacology 1985; 31: 57-60.

25. Ferri $S$, Arrigo-Reina R, Candeletti S, Costa G, Murari G, Speroni E, Scoto G. Central and peripheral sites of action for the protective effect of opioids of the rat stomach. Pharmacol Res Commun 1983; 15: 409-18.

26. Carter CS, Altemus M. Integrative functions of lactational hormones in social behavior and stress management. Ann N Y Acad Sci 1997; 807: 164-74.

27. Windle RJ, Wood $S$, Shanks N, Perks $P$, Conde GL, da Costa AP, Ingram CD, Lightman SL. Endocrine and behavioural responses to noise stress: comparison of virgin and lactating female rats during non-disrupted maternal activity. J Neuroendocrinol 1997; 9: 407-14.

28. Neumann ID. Involvement of the brain oxytocin system in stress coping: interactions with the hypothalamo-pituitary-adrenal axis. Prog Brain Res 2002; 139: 147-62.

29. Petersson M, Hulting AL, Uvnas-Moberg K. Oxytocin causes a sustained decrease in plasma levels of corticosterone in rats. Neurosci Lett 1999; 264: 41-4.

30. Uvnas-Moberg K. Oxytocin may mediate the benefits of positive social interaction and emotions. Psychoneuroendocrinol 1998; 23: 819-35.

31. Uvnas-Moberg $K$, Ahlenius $S$, Hillegaart $V$, Alster $P$. High doses of oxytocin cause sedation and low doses cause an anxiolytic-like effect in male rats. Pharmacol Biochem Behav 1994; 49: 101-6.

32. Slattery DA, Neumann ID. Chronic icv oxytocin attenuates the pathological high anxiety state in female high anxiety-related behaviour rats. Neuropharmacology 2010; 58: 56-61.

33. İşeri SÖ, Düşünceli F, Erzik C, Uslu B, Arbak S, Yeğen BÇ. Oxytocin or Social Housing Alleviates Local Burn Injury in Rats. Journal of Surgical Research 2010; 162: 122-31.

34. Mulhisen L, Rogers JZ. Complementary and alternative modes of therapy for the treatment of the obese patient. J Am Osteopath Assoc 1999; 99: 8-12.

35. Plotnikoff NP, Murgo AJ, Miller GC, Corder CN, Faith RE. Enkefalins: Immunomodulators. Federation Proc 1985; 44: 118-22.

36. Malizia E, Andreucci G, Paolucci D, Crescenzi F, Fabbri A, Fraioli F. Electroacupuncture and peripheral beta endorphin and ACTH levels. Lancet 1979; ii: 535-6.

37. Cabığlu MT, Ergene N. Effects of Acupuncture and Clinical Applications. Genel Tip Derg 2003; 13: 35-40.
38. Pan B, Castro-Lopes JM, Coimbra A. Activation of anterior lobe corticotrophs by electroacupuncture or noxious stimulations in the anaesthetized rat, as shown by colocalization of fos protein with ACTH and $\beta$-endorphin and increased hormone release. Brain Res Bull 1996; 40: 175-82.

39. Li SJ, Tang J, Han JS. The implication of central serotonin in electroacupuncture tolerance in rat. Sci Sin 1982; 25: 620-9.

40. Guyton AC, Hall JE. Textbook of medical physiology. WB Saunders, Philadelphia. 2001, pp.689-696.

41. Ullet GA, Han S, Han JS. Electroacupuncture: Mechanism and clinical application. Biol Psychiatry 1998; 44: 129-38.

42. Yang J, Yang $Y$, Chen JM, Liu WY, Wang $\mathrm{CH}$, Lin BC. Effect of oxytocin on acupuncture analgesia in the rat. Neuropeptides 2007; 41: 285-92.

43. Çetinel Ş, Hancıoğlu S, Şener E, Üner C, Kılıç M, Şener $\mathrm{G}$, Yeğen BÇ. Oxytocin treatment alleviates stress-aggravated colitis by a receptor-dependent mechanism Regul Peptides 2010; 160: 146-52.

44. Cabığlu MT, Çetin N, Ergene N, Gündoğan NÜ. Obesity treatment with $2 \mathrm{~Hz}$ Frequency Electroacupuncture and diet together or only diet. Weight lose, Beta endorphin, ACTH and Cortisol levels. Selçuk Üniv Tıp Derg 2008; 25: 7-15.

45. Wang SM, Kain ZN. Auricular acupuncture: A potential treatment for anxiety. Anesth Analg 2001; 92: 548-53.

46. Maciocia G. Liver patterns. In: The Foundations of Chinese medicine. Editor: G. Maciocia, Churchill Livingstone, New York. 1989, pp. 215-229.

47. Cabıoğlu MT, Ergene N, Tan U. Electroacupuncture Treatment of Obesity with Psychological Symptoms. Int. J. Neurosci 2007; 117: 579-90.

48. Chang CL, Lee JC, Tseng CC, Chang YH, Cheng JT. Decrease of anesthetics activity by electroacupuncture on Jen-Chung point in rabbits. Neurosci Lett 1995; 202: 93-6.

49. Chang FC, Tsai HY, Yu MC, Yi PL, Lin JG. The central serotonergic system mediates the analgesic effect of electroacupuncture on Zusanli (ST36) acupoints. J Biomed Sci. 2004; 11: 179-85.

50. Guo ZL, Longhurst JC. Expression of c-Fos in arcuate nucleus induced by electroacupuncture: relations to neurons containing opioids and glutamate. Brain Res. 2007; 1166: 65-76.

51. Kishioka S, Miyamoto $Y$, Fukunaga $Y$, Nishida S, Yamamoto H. Effects of a mixture of peptidase inhibitors (amastatin, captopril and phosphoramidon) on Met-enkephalin, beta-endorphin, dynorphin-(1-13)- and electroacupuncture-induced antinociception in rats. Jpn J Pharmacol 1994; 66: 337-45.

52. Zhou L, Wu GC, Cao XD. Role of opioid peptides of rat's nucleus reticularis paragigantocellularis lateralis (RPGL) in acupuncture analgesia. Acupunct Electrother Res. 1995; 20: 89-100.

53. Warren DS, Kayumov L, Chen A, Lowe A, Jain U, Katzman MA, Shen J. Acupuncture Increases Nocturnal Melatonin Secretion and Reduces Insomnia and Anxiety. A Preliminary Report. J Neuropsych Clin N 2004; 16: 19-28.

54. Yeung WF, Chung KF, Zhang SP, Yap TG, Andrew CK. Electroacupuncture for Primary Insomnia: A Randomized Controlled Trial. Sleep 2009; 32: 1039-47. 
55. Han Z, Jiang YH, Wan $Y$, Wang $Y$, Chang JK, Han JS. Endomorphin- 1 mediates $2 \mathrm{~Hz}$ but not $100 \mathrm{~Hz}$ electroacupuncture analgesia in the rat. Neurosci Lett 1999; 274: 75-8.

56. Balk J, Catov J, Horn B, Gecsi K, Wakim A. The relationship between perceived stress, acupuncture, and pregnancy rates among IVF patients: A pilot study. Complement Ther Clin Pract 2010; 16: 154-7.

57. Herd J. Cardiovascular response to stress. Physiol Rev 1991; 71: 305-27.

58. Chan C, Briscomb D, Waterhause E, Cannaby A-M. An uncontrolled pilot study of HT7 for "stress". Acupunct Med 2002; 20: 74-7.

59. Apostolopoulos A, Karavis M. Overeating: Treatment of obesity and anxiety by auricular acupuncture, an analysis of 800 cases. Acupunct Med 1996; 14: 116-20.
60. Dong JT. Research on the reduction of anxiety and depression with acupuncture. Am J Acupunct 1993; 21: 327-30.

61. Guizhen L, Yunjun Z, Linxiang G, Aizhen L. Comparative study on acupuncture combined with behavioral desensitization for treatment of anxiety neuroses. Am J Acupunct 1998; 26: 117-20.

62. Pavao TS, Vianna $P$, Pillat MM, Machado AB, Bauer ME. Acupuncture is effective to attenuate stress and stimulate lymphocyte proliferation in the elderly. Neurosci Lett. 2010; 484: 47-50.

63. Şahin NH. Coping with stress: a positive approach. Turk J Psychol 1994; 2: 1-16.

64. Fields L, Printz RJ. Coping and adjustment during childhood and adolescence. Clin Psychol Rev 1997; 17: 937-76. 